\title{
PENERAPAN METODE DEMONSTRASI UNTUK MENINGKATKAN PRESTASI BELAJAR IPA TENTANG PERUBAHAN WUJUD BENDA BAGI SISWA KELAS IV DI SD INPRES 54 MAKBUSUN KABUPATEN SORONG
}

\author{
SISWANDRI
}

\author{
SD Inpres 54 Makbusun Kabupaten Sorong
}

\begin{abstract}
ABSTRAK
Penelitian ini bertujuan untuk mengetahui peningkatan Prestasi Belajar IPA Tentang Perubahan Wujud Benda bagi siswa Kelas IV di SD Inpres 54 Makbusun melalui pemanfaatan Metode Demontrasi. Jenis penelitian ini adalah penelitian tindakan kelas (Classroom Action Research) yang dilakukan secara kolaboratif antara peneliti dengan guru teman sejawat. Penelitian dilaksanakan dalam dua siklus, masing-masing siklus terdiri dari empat komponen yaitu perencanaan, tindakan, pengamatan dan refleksi. Teknik pengumpulan data yang digunakan dalam penelitian ini adalah wawancara, observasi, dokumentasi dan tes. Analisis data dilakukan dalam 3 tahap yaitu reduksi, penyajian data serta menarik kesimpulan. Hasil penelitian menunjukkan bahwa: Pemanfaatan Metode Demontrasi dapat meningkatkan prestasi belajar siswa.Pertasi belajar siswa meningkat karena siswa lebih aktif dalam pembelajaran dengan menggunakan metode demonsrasi. Peningkatan prestasi belajar siswa dapat dilihat dari rata-rata hasil belajar pada setiap siklus. Rata-rata hasil belajar siswa pada siklus I sebesar 69.18 meningkat menjadi 80.45 pada siklus II.
\end{abstract}

Kata kunci : Demonstrasi, Prestasi, IPA

\begin{abstract}
This study aims to determine the increase in Natural Science Learning Achievement about Changes in Objects for Class IV students at SD Inpres 54 Makbusun through the use of the Demonstration Method. This type of research is a Classroom Action Research conducted collaboratively between researchers and teacher peers. The study was conducted in two cycles, each cycle consisting of four components, namely planning, action, observation and reflection. Data collection techniques used in this study were interviews, observation, documentation and tests. Data analysis was carried out in 3 stages namely reduction, presentation of data and drawing conclusions. The results of the study show that: Utilization of the Demonstration Method can improve student learning achievement. The percentage of student learning increases because students are more active in learning by using the demonstration method. Improved student achievement can be seen from the average learning outcomes in each cycle. The average student learning outcomes in the first cycle of 69.18 increased to 80.45 in the second cycle. Keywords: Demonstrations, Achievements, Natural Sciences
\end{abstract}

\section{PENDAHULUAN}

Pendidikan a dalah upaya untuk mencerdaskan kehidupan bangsa, dimana setiap warga negara berhak a tas pendidikan itu. Dengan a danya pendidikan maka manusia dapat memperkaya diri dan mencapai taraf kebudayaan yang lebih tinggi, sehingga masing-masing manusia a kan mengalami perkembangan di berbagai bidang kehidupan.

Pendidikan Sekolah Dasar bukan hanya memberikan bekal kemampuan intlektual, dasar dalam membaca, menulis dan berhitung saja melainkan juga berbagai proses pengembangan kemampuan dasar peserta didik secara optimal dalam segala a spek.

Beberapa hal yang berpengaruh bagi peserta didik diantaranya sarana-prasarana, motivasi belajar siswa dalam proses pembelajaran, serta profesionalisme guru, semangat siswa belajar terkadang menurun sehingga terkadang proses pembelajaran menjadi kurang menarik terutama pada jam-jam pelajaran terakhir.

Pada hakekatnya kegiatan belajar mengajar adalah suatu proses interaksi atau hubungan timbal balik antara guru dan siswa dalam satuan pembelajaran. Guru sebagai salah satu komponen dalam proses belajar menganjar merupakan pemegang peran yang sangat penting. Guru bukan hanya sekedar penyampai materi saja, tetapi lebih dari itu guru dapat dikatakan sebagai sentral pembelajaran.

Guru mengemban tugas yang berat untuk tercapainya tujuan pendidikan nasional yaitu meningkatkan kualitas manusia Indonesia, manusia seutuhnya yang beriman dan bertakwa terhadap Tuhan Yang Maha Esa, berbudi pekerti luhur, berkepribadian, berdisiplin, bekerja keras, tangguh, bertanggung jawab, mandiri, cerdas dan terampil serta sehat jasmani dan rohani, juga harus mampu menumbuhkan dan memperdalam rasa cinta terhadap tanah air, mempertebal semangat kebangsaan dan rasa kesetiakawanan sosial. Sejalan dengan itu pendidikan nasional akan mampu mewujudkan manusia-manusia pembangunan dan membangun dirinya sendiri serta bertanggung jawab atas pembangunan bangsa. Depdikbud (1999).

Berhasilnya tujuan pembelajaran ditentukan oleh banyak faktor diantaranya adalah faktor guru dalam melaksanakan proses belajar mengajar, karena guru secara langsung dapat mempengaruhi, membina dan meningkatkan kecerdasan serta keterampilan siswa. Untuk mengatasi permasalahan di atas dan guna mencapai tujuan pendidikan secara maksimal, peran guru sangat penting dan diharapkan guru memiliki 
cara/model mengajar yang baik dan mampu memilih motode pembelajaran yang tepat dan sesuai dengan konsep-konsep mata pelajaran yang akan disampaikan.

Mata pelajaran Ilmu Pengetahuan Alam merupakan mata pelajaran utama di sekolah dasar. Pembelajaran mata pelajaran ini biasa diajarkan secara konvensional hampir di setiap sekolah dasar, dengan metode klasik ceramah sehingga menciptakan kejenuhan dalam lingkungan belajar, dikarenakan siswa hanya cenderung mendengar dan mendengarkan. Dan hal tersebut menyebabkan kurangnya pemahaman siswa terhadap suatu materi a jar. Hal ini dapat dilihat dari hasil tes akhir pembelajaran mata pelajaran IPA pada materi Perubahan Wujud Benda , dari jumlah siswa kelas IV sebanyak 22 siswa dengan KKM 65 , hanya 7 siswa yang mampu mencapai KKM atau sekitar 31,81 \%, sedangkan yang 15 siswa atau 68,18\% belum mencapai KKM, adapun rata-rata kelas hanya mencapai 60, 23. Oleh sebab itu penggunaan metode pembelajaran dirasa sangat penting untuk membantu siswa dalam memahami konsep-konsep IPA.

Metode pembelajaran jenisnya beragam yang masing-masing memiliki kelebihan dan kelemahan, maka pemilihan metode yang sesuai dengan topik atau materi yang akan diajarkan harus betul-betul dipikirkan oleh guru yang akan menyampaikan materi pelajaran.

Dari permasalahan tersebut, peneliti merasa bahwa kemampuan menguasai materi Perubahan Wujud Benda perlu dipahami siswa. Hal ini di karenakan nilai rata-rata kelas belum mencapai KKM yang diharapkan. Selain itu saat ditanya guru siswa tidak mampu menjawab. Saat kegiatan belajar mengajar suasana kelas sangat monoton sehingga perlu dicari strategi pembelajaran yang merangsang siswa untuk aktif, kreatif, dan menyenangkan.

Berdasarkan uraian di atas maka penulis tertarik untuk melakukan penelitian dengan mengambil judul "Penerapan Metode Demonstrasi Untuk Meningkatkan Prestasi Belajar IPA Tentang Perubahan Wujud Benda Bagi Siswa Kelas IV Di SD Inpres 54 Makbusun Kabupaten Sorong Tahun 2013”. Penelitian ini bertujuan untuk mengetahui peningkatan prestasi belajar IPA tentang Perubahan Wujud Benda melalui Metode Demonstrasi bagi siswa kelas IV di SD Inpres 54 Makbusun Kabupaten Sorong Tahun 2013.

\section{METODE PENELITIAN}

Penelitian ini merupakan penelitian tindakan kelas (classroom action research), yaitu pencermatan terhadap kegiatan belajar berupa sebuah tindakan, yang sengaja dimunculkan dan terjadi dalam sebuah kelas secara bersama. Dalam pelaksanaannya peneliti dapat melakukan penelitian tindakan kelas secara mandiri ataupun kolaboratif, akan tetapi tidak boleh menghambat kegiatan utama guru dalam proses pembelajaran.

Penelitian ini dilakukan secara kolaboratif dan partisipatif. Secara partisipatif bersama-sama mitra peneliti melaksanakan penelitian ini langkah demi langkah. Selain partisipatif, peneliti dapat berkolaborasi dengan guru, dengan tujuan memperbaiki kekurangan-kekurangan dalam praktik pembelajaran. Dalam penelitian tindakan kelas ini, peneliti bertindak sebagai pelaksana tindakan sedangkan guru teman sejawat bertindak sebagai kolaborator.

Penelitian tindakan kelas ini dilakukan oleh peneliti, mencoba menemukan suatu gagasan yang kemudian diterapkan dalam upaya perbaikan pada praktik pembelajaran yang dilakukan. Dalam penelitian tindakan ini mencoba menerapkan variasi model pembelajaran yang baru yaitu pada model pembelajaran menggunakan Metode Demonstrasi yang diharapkan dapat memberikan perubahan ke arah perbaikan pada suatu proses pembelajaran.

Dalam penelitian tindakan kelas ini terdiri atas rangkaian empat kegiatan yang dilakukan dalam siklus berulang. Empat kegiatan utama yang ada pada setiap siklus, yaitu : 1. Perencanaan (planning), yaitu persiapan yang dilakukan untuk pelaksanaan PTK. 2. Tindakan (acting), yaitu deskripsi tindakan yang akan dilakukan, skenario kerja tindakan, perbaikan kerja yang akan dilakukan dan prosedur tindakan yang diterapkan. 3. Observasi (observing), yaitu kegiatan mengamati dampak atastindakan yang dilakukan. Kegiatan ini dapat dilakukan dengan cara pengamatan, wawancara atau cara lain yang sesuai dengan data yang dibutuhkan. 4. Refleksi (reflecting), yaitu kegiatan evaluasi tentang perubahan yang terjadi atau hasil yang diperoleh atas data yang terhimpun sebagai bentuk dampak tindakan yang telah dirancang. Berdasarkan langkah ini akan dapat diketahui perubahan yang terjadi dan dapat dilakukan tindakan sehingga mampu mencapai perubahan atau mengatasi masalah secara signifikan. Adapun siklusnya dapat digambarkan sebagai berikut :

Penelitian dilaksanakan di SD Inpres 54 Makbusun Kabupaten Sorong yang beralamat di Jl.

Jenderal Sudirman No.01. Kelurahan Makbusun Distrik Mayamuk Kabupaten Sorong. Pemilihan SD Inpres 54 Makbusun Kabupaten Sorong. Waktu penelitian adalah waktu berlangsungnya penelitian atau saat penelitian ini dilangsungkan..

Subjek dalam penelitian ini adalah siswa kelas IV SD Inpres 54 Makbusun Kabupaten Sorong. Sedangkan yang menjadi objek penelitian adalah prestasi belajar IPA materi perubahan wujud benda dengan pemanfaatan metode demonstrasi. Peneliti memilih siswa Kelas IV karena belum mencapai KKM untuk mata pelajaran Ilmu Pengetahuan Alam khususnya pada materi Perubahan Wujud Benda.

Variabel penelitian adalah objek penelitian yang menjadi pusat perhatian selama penelitian berlangsung dan penyusunan laporan. Dalam penelitian ini, yang menjadi variabel utama adalah, prestasi belajar dan Metode Demonstrasi.

Data diperoleh mealui observasi, wawancara, tes, dan teknik dokumentasi Instrumen yang digunakan dalam penelitian ini adalah: nontes (catatan lapangan, lembar observasi/ pengamatan, panduan wawancara, dokumentasi) dan tes 
Sebelum mengadakan penelitian, peneliti terlebih dahulu mengawali dengan pra-penelitian. Kegiatan ini dilakukan terhadap mata pembelajaran Ilmu Pengetahuan Alam sebelum menggunakan metode demonstrasi. Kegiatan yang dilakukan yaitu mengadakan observasi terhadap situasi awal di dalam kelas yang mencakup observasi kegiatan guru, observasi kelas dan observasi terhadap siswa. Setelah mengadakan kegiatan pra-penelitian, peneliti mengadakan penelitian di dalam kelas dengan menggunakan metode demonstrasi. Penelitian ini dilakukan dalam bentuk siklus, masing-masing siklus terdiri dari perencanaan, tindakan, pengamatan dan refleksi. Penelitian ini didesain sebagai Penelitian Tindakan Kelas (PTK) yang akan dilakukan dengan dua siklus. Adapun langkah-langkah setiap siklus adalah sebagai berikut: perencanaan, tindakan, monitoring tindakan dan refleksi

Dalam penelitian ini, peneliti mengecek kebenaran data yang diperoleh dari lembar observasi dalam proses pembelajaran, hasil wawancara dan dokumentasi yang dilaksanakan dengan siswa dan guru pada akhir tindakan untuk mempermudah dalam penarikan kesimpulan. Pada penelitian ini, triangulasi yang digunakan adalah triangulasi sumber dan triangulasi metode:

Analisis data yang digunakan dalam penelitian ini dilakukan terus menerus selama pengumpulan data berlangsung sampai pada akhir penelitian atau penarikan kesimpulan. Peneliti merefleksi hasil observasi terhadap proses pembelajaran yang dilaksanakan guru dan siswa di dalam kelas. Adapun yang dianalisis, adalah Prestasi Belajar Siswa dan Kriteria Keberhasilan. Prestasi belajar siswa dikatakan berhasil jika prestasi belajar 75\% siswa pada akhir siklus telah mencapai 65.

\section{PEMBAHASAN}

Dari hasil pengamatan yang dilakukan oleh peneliti, prestasi belajar pada mata pelajaran Ilmu Pengetahuan Alam siswa Kelas IV Di SD Inpres 54 Makbusun Kabupaten Sorong dikatakan rendah karena masih ada 15 siswa atau 68,18 \% yang nilainya di bawah 65 yang merupakan Kriteria Ketuntasan Minimal (KKM) yang telah ditentukan sekolah dengan melihat hasil ulangan harian. Hal ini disebabkan guru masih menggunakan metode ceramah dan monoton sehingga siswa menjadi pasif dan kurang aktif dalam mengikuti proses pembelajaran. Hal ini apabila tidak ditindaklanjuti tentu akan mengakibatkan proses pembelajaran tidak optimal dan mempengaruhi prestasi belajar.

Hasil Observasi observasi siklus 1 ditampilkan pada tabel 3.1.Dari tabel dapat diketahui bahwa siswa yang mendengarkan penjelasan sebanyak $68,18 \%$ mencatat penjelasan 68,18 \% memperhatiakan pembelajaran 63,64 \% , bertanya 63,64 \% menjawab pertanyaan 68,18 \%, mengeluarkan pendapat 59,09 \%, menghargai pendapat teman 68,18 \% mampu menjelaskan kembali 63,64\%.

Tabel 1. Hasil Observasi Partisipasi Aktif Siswa pada Siklus I

\begin{tabular}{|l|l|l|l|l|c|}
\hline \multirow{2}{*}{\multicolumn{1}{c|}{ Aspek yang diamati }} & \multirow{2}{*}{$\sum$ siswa total } & \multicolumn{5}{c|}{ Partisipasi Aktif } \\
\cline { 3 - 6 } & & $\sum$ siswa & $\mathbf{( \% )}$ & $\sum$ siswa & $\mathbf{( \% )}$ \\
\hline Mendengarkan Penjelasan & 22 & 15 & 68,18 & 18 & 81,82 \\
\hline Mencatat penjelasan & 22 & 15 & 68,18 & 17 & 77,27 \\
\hline Memperhatikan pembelajaran & 22 & 14 & 63,64 & 19 & 86,36 \\
\hline Bertanya & 22 & 14 & 63,64 & 18 & 81,82 \\
\hline Menjawab pertanyaan & 22 & 15 & 68,18 & 17 & 77,27 \\
\hline Mengeluarkan pendapat & 22 & 13 & 59,09 & 18 & 81,82 \\
\hline Menghargai pendapat teman & 22 & 15 & 68,18 & 17 & 77,27 \\
\hline Mampu menjelaskan kembali & 22 & 14 & 63,64 & 16 & 72,73 \\
\hline
\end{tabular}

Data yang diperoleh melalui tes dihitung jumlah nilai yang diperoleh masing-masing siswa dengan cara mengakumulasikan masing-masing nilai pada setiap item soal yang dijawab siswa. Secara lengkap hasil tes pelaksanaan siklus I dapat dilihat pada Tabel 3.2. Berdasarkan rata-rata siswa pada post test siklus I dapat diketahui nilai sebesar 69,18. Hal ini menunjukkan bahwa terjadi peningkatan prestasi belajar siswa setelah menggunakan Metode Demonstrasi pada mata pelajaran Ilmu Pengetahuan Alam tentang Perubahan Wujud Benda. Namun berdasarkan nilai siswa pada siklus 1 di atas, kriteria keberhasilan belum tercapai, karena masih terdapat 8 siswa belum mencapai KKM, sehingga perlu dilanjutkan dengan siklus berikutnya yaitu siklus II.

Tabel 2. Hasil Perhitungan Tes pada Siklus 1

\begin{tabular}{|l|l|l|l|l|}
\hline \multirow{2}{*}{ Nama Siswa } & \multicolumn{2}{|l|}{ SIKLUS 1 } & \multicolumn{2}{l|}{ SIKLUS 2} \\
\cline { 2 - 5 } & Tes & KETUNTASAN & Tes & KETUNTASAN \\
\hline
\end{tabular}




\begin{tabular}{|l|l|l|l|l|l|l|}
\hline & & Tuntas & Belum & & Tuntas & Belum \\
\hline Aldy .M. Yusuf & 70 & $\sqrt{ }$ & & 80 & $\sqrt{ }$ & \\
\hline Ferdinandus Majefat & 70 & $\sqrt{ }$ & & 60 & & $\sqrt{ }$ \\
\hline Fince Sesa & 50 & & $\sqrt{ }$ & 80 & $\sqrt{ }$ & \\
\hline Iqbal Adi Saputra & 60 & & $\sqrt{ }$ & 80 & $\sqrt{ }$ & \\
\hline Martina Kamesrar & 70 & $\sqrt{ }$ & & 80 & $\sqrt{ }$ & \\
\hline Kusuma Galuh & 63 & & $\sqrt{ }$ & 80 & $\sqrt{ }$ & \\
\hline Nisa Ratnawati & 64 & & $\sqrt{ }$ & 70 & $\sqrt{ }$ & \\
\hline Atina .M. Ambarani & 63 & & $\sqrt{ }$ & 80 & $\sqrt{ }$ & \\
\hline Arya .H. Laksono & 70 & $\sqrt{ }$ & & 80 & $\sqrt{ }$ & \\
\hline Aditya .P. Pranoto & 62 & & $\sqrt{ }$ & 80 & $\sqrt{ }$ & \\
\hline Bonivasius .S. Wambon & 70 & $\sqrt{ }$ & & 80 & $\sqrt{ }$ & \\
\hline Cindy .Y. Pattiruhu & 60 & & $\sqrt{ }$ & 90 & $\sqrt{ }$ & \\
\hline Dwi .N. Pujayanti & 70 & $\sqrt{ }$ & & 80 & $\sqrt{ }$ & \\
\hline Hafsawiah Febrianti & 70 & $\sqrt{ }$ & & 100 & $\sqrt{ }$ & \\
\hline M. Gilang Prayogi & 60 & & $\sqrt{ }$ & 100 & $\sqrt{ }$ & \\
\hline Rendy Friandhana & 90 & $\sqrt{ }$ & & 90 & $\sqrt{ }$ & \\
\hline Sintiya .A.Nigrum & 80 & $\sqrt{ }$ & & 80 & $\sqrt{ }$ & \\
\hline Wahyun Meidarwati & 90 & $\sqrt{ }$ & & 60 & & $\sqrt{ }$ \\
\hline Yermina .P. Lokden & 70 & $\sqrt{ }$ & & 80 & $\sqrt{ }$ & \\
\hline Aldiansya & 80 & $\sqrt{ }$ & & 80 & $\sqrt{ }$ & \\
\hline Datu Afriansya & 70 & $\sqrt{ }$ & & 80 & $\sqrt{ }$ & \\
\hline Romi .A. Bahtiar & 70 & $\sqrt{ }$ & & 80 & $\sqrt{ }$ & \\
\hline
\end{tabular}

Dalam pembelajaran pada siklus 1 ini, tahap refleksi dilakukan oleh peneliti dan guru kolaborator untuk mengevaluasi hasil observasi partisipasi aktif siswa dan hasil dari pelaksanaan post test sebagai umpan balik setelah pembelajaran. Penggunaan Metode Demonstrasi meskipun belum maksimal, sebenarnya sudah menunjukkan partisipasi aktif siswa. Masih banyak siswa yang cenderung enggan untuk mengemukakan pendapat dan hal tersebut dikarenakan siswa belum terbiasa di dalam pembelajaran menggunakan Metode Demonstrasi, sehingga masih banyak siswa yang pasif dalam mengikuti pembelajaran. Pada pelaksanaan pembelajaran menggunakan Metode Demonstrasi untuk meningkatkan partisipasi aktif siswa pada siklus 1 belum sepenuhnya terlaksana dengan baik. Hal ini terjadi, mungkin dikarenakan siswa masih canggung dengan pembelajaran menggunakan Metode Demonstrasi, Prestasi belajar pada siklus 1 juga belum menunjukkan hasil yang maksimal, meskipun telah banyak siswa yang memenuhi kriteria ketuntasan minimal tetapi masih ada juga siswa yang belum memenuhi.

Berdasarkan hasil refleksi tersebut, maka perlu adanya tindakan lanjutan untuk memperbaiki atau menyempurnakan pembelajaran dengan menggunakan Metode Demonstrasi. Dikarenakan belum tercapainya target tindakan yang diinginkan pada pelaksanaan tindakan pada siklus 1, maka peneliti dan guru sepakat untuk melanjutkan tindakan pada siklus II.

Hasil observasi siklus 2 ditampilkan pada Tabel 3.1. Dari tabel 3.1. dapat diketahui bahwa siswa yang mendengarkan penjelasan sebanyak 81,82 \% mencatat penjelasan 77,27 \% memperhatiakan pembelajaran $86,36 \%$, bertanya $81,82 \%$ menjawab pertanyaan
$77,27 \%$, mengeluarkan pendapat $81,82 \%$, menghargai pendapat teman $77,27 \%$ mampu menjelaskan kembali $72,73 \%$.

Data yang diperoleh melalui tes ditampilkan pada Tabel 3.2. Berdasarkan rata-rata hasil belajar antara tes pada siklus I dan siklus II yang diketahui bahwa pada tes II 80,45 mempunyai rata-rata lebih tinggi dibandingkan dengan rata-rata pada tes yang dilakukan di siklus I 69,18. Hal ini menunjukkan adanya peningkatan pada prestasi belajar pada siklus II dalam mata pelajaran Ilmu Pengetahuan Alam tentang Perubahan Wujud Benda. Berdasarkan rata-rata pada siklus II di atas, kriteria keberhasilan sudah tercapai karena lebih dari 75\% siswa telah mencapai KKM, bahkan 90,90 \% siswa mencapai KKM, hal ini menunjukkan adanya pencapaian tingkat keberhasilan sesuai dengan kriteria keberhasilan yang telah ditetapkan.

Pada tahap refleksi peneliti bersama guru teman sejawat mengevaluasi hasil dari tes dan observasi, dari hasil pengamatan dan refleksi di siklus II maka penerapan Metode Demonstrasi dapat meningkatkan partisipasi aktif dan prestasi belajar siswa. Pada hasil partisipasi aktif siswa, siswa telah berpartisipasi secara aktif dalam pembelajaran dan keaktifan siswa pada proses pembelajan berlangsung dapat dilihat pada dokumentasi berupa foto-foto yang telah terlampir dalam lampiran, sedangkan pada hasil belajar semua siswa sudah mencapai ketuntasan yang telah ditetapkan yaitu memperoleh nilai $\geq 65$ untuk masing-masing siswa pada siklus ke II yaitu mencapai rata-rata 80,45 Jadi dari hasil pengamatan dan refleksi di siklus II penggunaan Metode Demonstrasi dapat meningkatkan partisipasi aktif dan prestasi belajar siswa. Hal ini dikarenakan dengan menggunakan Metode 
Demonstrasi, siswa lebih tertarik dan mempunyai motivasi yang tinggi untuk belajar. Keunggulan yang ada perlu dipertahankan untuk mendukung peningkatan dalam penggunaan metode pembelajaran selanjutnya. Sedangkan beberapa kelemahan dalam penerapan metode demontrasi perlu diperbaiki untuk pertemuan selanjutnya. Berdasarkan hasil tes dan hasil observasi dari siklus II yang telah terjadi peningkatan dari siklus I, peneliti dan guru sepakat bahwa penelitian ini tidak dilanjutkan ke siklus III.

Dalam penelitian ini, pembahasan lebih difokuskan pada; pelaksanaan penelitian tindakan kelas menggunakan Metode Demonstrasi, dan peningkatan prestasi belajar siswa dalam mata pelajaran Ilmu Pengetahuan Alam tentang Perubahan Wujud Benda.

Pelaksanaan Metode Demonstrasi untuk meningkatkan prestasi belajar siswa dilakukan dalam dua siklus dan dilaksanakan di kelas. Penerapan Metode Demonstrasi pada siklus I telah dilakukan oleh guru,tetapi di dalam pelaksanaannya belum tercipta peningkatan partisipasi aktif dan prestasi belajar siswa secara maksimal, maka peneliti sepakat untuk melanjutkan pada siklus berikutnya yaitu siklus II. Siklus demi siklus terbentuk untuk memberikan perbaikan dan perbandingan di dalam pembelajaran agar partisipasi aktif dan prestasi belajar lebih meningkat sesuai dengan apa yang diharapkan peneliti.

Dari pernyataan tersebut dapat disimpulkan bahwa mata pelajaran Ilmu Pengetahuan Alam dengan menggunakan Metode Demonstrasi ini dapat memberi kemudahan bagi siswa dalam memahami materi yang diberikan guru. Dalam pembelajaran siklus I masih ada siswa yang kurang dapat memahami materi pelajaran, permasalahan yang diberikan oleh guru serta belum semua siswa menunjukkan partisipasi aktif selama proses pembelajaran dengan menggunakan Metode Demonstrasi ini. Akan tetapi setelah siklus II para siswa berangsur-angsur dapat memahami materi, serta hampir semua siswa berpartisipasi aktif selama proses pembelajaran dengan menggunakan Metode Demonstrasi. Untuk menilai kriteria keberhasilan prestasi belajar siswa, peneliti menggunakan kriteria ketuntasan minimal (KKM) untuk mata pelajaran IPA yang ditetapkan SD Inpres 54 Makbusun Kabupaten Sorong Tahun Pelajaran 2013/2014 sebesar 65. Dalam mengadakan penilaian peneliti mengukur keberhasilan prestasi siswa menggunakan soal setelah tindakan dilakukan.

Penilaian yang digunakan pada setiap siklus adalah dengan menggunakan tes dan dilaksanakan pada setiap akhir siklus dengan soal-soal yang sesuai dengan materi yang diberikan kepada siswa. Hal ini dilakukan untuk mengukur sejauh mana siswa dapat menguasai materi yang telah disampaikan menggunakan Metode Demonstrasi. Hasil penelitian tindakan siklus I dan II dengan penggunaan Metode Demonstrasi menunjukkan adanya peningkatan terhadap prestasi belajar siswa.

Dari pernyataan tersebut, dapat disimpulkan bahwa dengan menggunakan Metode Demonstrasi dapat menaikkan ingatan yang berarti dapat meningkatkan pestasi belajar siswa. Setelah dilakukan penelitian yang dimulai dari tahapan siklus I, sampai pada tahapan siklus II dapat dilihat adanya peningkatan partisipasi aktif dan prestasi belajar siswa dengan menggunakan Metode Demonstrasi. Berdasarkan pemaparan prestasi belajar di atas dapat diberikan penjelasan bahwa telah terjadi peningkatan prestasi belajar siswa dari siklus I mencapai rata-rata 63,63\% naik menjadi rata-rata 90,90 \% pada tahap siklus II. Dari rata-rata tersebut dapat diketahui peningkatan rata-rata 27,27 \% dari siklus I ke siklus II. Dapat disimpulkan bahwa dengan penggunaan Metode Demonstrasipada mata pelajaran Ilmu Pengetahuan Alam dapat meningkatkan prestasi belajar siswa.

Peningkatan prestasi belajar dapat dilihat pada diagram sebagai Berikut: Peningkatan rata-rata nilai hasil belajar dari siklus I sebesar 69.18 sedangkan pada siklus II meningkat menjadi sebesar 80.45. Peningkatan nilai tertinggi yang diperoleh siswa dari siklus I sebesar 90 sedangkan pada siklus II meningkat menjadi sebesar 100. Peningkatan nilai terendah yang diperoleh siswa dari siklus I sebesar 50 sedangkan pada siklus II meningkat menjadi sebesar 60. Peningkatan jumlah tuntas individu atau siswa yang mencapai Kriteria Ketuntasan Minimal (KKM) dari siklus I sebesar 14 siswa sedangkan pada siklus II meningkat menjadi sebesar 20 siswa. Peningkatan persentase ketuntasan individu. Siklus I terdapat 63.63 \% siswa yang telah mencapai ketuntasan atau mencapai Kriteria Ketuntasan Minimal (KKM). Sedangkan pada siklus II terdapat 90.90 \% siswa telah mencapai KKM.

\section{KESIMPULAN}

Berdasarkan hasil analisis data dan pembahasan yang telah peneliti lakukan, aktivitas dan prestasi belajar siswa Kelas IV di SD Inpres 54 Makbusun Kabupaten Sorong untuk mata pelajaran Ilmu Pengetahuan Alam, dapat ditarik kesimpulan sebagai berikut: 1. Metode Demonstrasi dapat meningkatkan partisipasi aktif siswa pada mata pelajaran Ilmu Pengetahuan Alam di kelas. Peningkatan partisipasi aktif siswa ini dapat dilihat dari adanya peningkatan presentae keaktifan siswa dari siklus I dan Siklus II. Hal tersebut membuktikan bahwa dengan menggunakan Metode Demonstrasi dapat meningkatkan partisipasi aktif siswa 2. Metode Demonstrasi dapat meningkatkan prestasi belajar siswa pada mata pelajaran Ilmu Pengetahuan Alam di kelas. Peningkatan hasil belajar ini dapat dilihat dari adanya perubahan nilai rata-rata yang diperoleh siswa pada setiap akhir siklus. Nilai rata-rata yang diperoleh siswa pada siklus I sebesar 69.18 dan siklus II sebesar 80.54 Hal tersebut membuktikan bahwa dengan menggunakan Metode Demonstrasi dapat meningkatkan prestasi belajar siswa.

\section{DAFTAR PUSTAKA}

Djamarah, Syaiful Bahri. 2000. Strategi Belajar Mengajar. Jakarta: Rineksa Cipta.

Departemen Pendidikan Nasional. (2006). Panduan 
Kurikulum Satuan Tingkat Pendidikan ( KTS ) SD/MI. Jakarta : Depdiknas.

Haryanto. 2007. Sains untuk Sekolah Dasar Kelas IV. Jakarta: Erlangga

Hendro Darmojo dan Jenny R.E Kaligis. (1992). Pendidikan IPA 2. Jakarta: Departemen Pendidikan dan Kebudayaan. Mulyasa. (2004). Menjadi Guru professional. Bandung: PT Remaja Rosdakarya.

Nana Sudjana. (2006). Penilaian Hasil Proses Belajar Mengajar. Bandung: PT Remaja Rosdakarya.

Poerwadarminta. 1984. Kamus Umum Bahasa Indonesia. Jakarta: Depdiknas

Riduwan (2009) Skala Variabel-Variabel Penelitian Bandung: Alfabeta.

Rochiati Wiriaatmadja. (2009). Metode Penelitian Tindakan Kelas. Bandung: PT Remaja Rosdakarya.
Sagala, Syaiful. 2010. Konsep dan Makna Pembelajaran. Bandung: ALFABETA

Slameto. (2010). Belajar dan Faktor-Faktor yang Mempengaruhi. Jakarta: Rineka Cipta.

Sugihartono. (2007). Psikologi Pendidikan. Yogyakarta: UNY Press.

Suharsimi Arikunto. (2009). Dasar-dasar Evaluasi Pendidikan (Edisi Revisi, cetakan 7). Jakarta: Bumi Aksara

Suharsimi Arikunto, dkk. (2013). Penelitian Tindakan Kelas. Jakarta : Bumi Aksara.

Sumadi Suryabrata. (2006). Psikologi Pendidikan. Jakarta: PT Raja Grafindo Persada.

Suryobroto. (1997). Proses Belajar Mengajar di Sekolah. Jakarta: PT Rineka Cipta.

Susilo. (2007). Panduan Penelitian Tindakan Kelas. Yogyakarta: Pustaka Book Publlisher.

Usman, Moh. Uzer. 2001. Menjadi Guru Profesional. Bandung: Remaja Rosdakarya. 